\title{
An Update on Modes and Timing of Gamete and Planula Release in Hawaiian Scleractinian Corals with Implications for Conservation and Management ${ }^{1}$
}

\author{
Steven P. Kolinski and Evelyn F. Cox ${ }^{2}$
}

\begin{abstract}
Reproductive data for 24 of the 50 plus species of scleractinian corals in Hawai' $i$ are available. A majority of species (75\%) are broadcast spawners, just over half $(58 \%)$ of which are hermaphrodites. Peak reproduction of Hawaiian corals occurs during summer months, although reproduction continues yearround for some brooders. Timing, duration, mode, and location of reproductive processes have implications for disturbance management, assessment, and conservation of reef corals.
\end{abstract}

The minimization of human impacts on coral reef dynamics is critical to maintaining coral reef diversity and reef ecosystem functions. Human impacts can be direct and/or indirect, affecting reef organisms during one or more of a variety of life history stages (Brown and Howard 1985, Richmond 1993, 1997, Raimondi and Reed 1996). Sexual reproduction in scleractinian corals involves a number of discrete stages that occur in different zones of the marine environment. These fundamental stages include gamete development (internal to the organism), gamete release (internal coordination leading to external release), fertilization (internal, or external in the water column, at the water surface, or on the benthos), embryonic and larval development (internal, or external in the water column or at the water surface), dispersal (external in the water column and/or at the water surface), settlement, and metamorphosis (external on a substrate) (Harrison and Wallace 1990, Richmond 1993, 1997). Synchronization of various reproductive stages within populations is fundamental to increasing the likelihood of reproductive success

1 This is contribution no. 1128 of the Hawai'i Institute of Marine Biology. Manuscript accepted 22 March 2002.

2 Hawai'i Institute of Marine Biology, P.O. Box 1346, Coconut Island, Kāne'ohe, Hawai'i 96744.

Pacific Science (2003), vol. 57, no. 1:17-27

(C) 2003 by University of Hawai'i Press

All rights reserved
(Harrison and Wallace 1990, Levitan 1995, Morgan 1995, Coma et al. 1998). Individual stages may differ in their exposure, vulnerability, and susceptibility to various impacts (Richmond 1993, 1997).

Understanding where and when reproductive processes take place allows for a precautionary approach to minimizing human interference with coral reproductive dynamics. In this paper we summarize available data for reproduction in Hawaiian corals in an effort to provide information pertinent to mitigating human impacts on coral reproduction and population dynamics.

\section{MATERIALS AND METHODS}

Data summarized in this report resulted from both direct and indirect observations of gamete formation and release in laboratory and/ or field settings. Information for the majority of species came from studies conducted at the Hawai'i Institute of Marine Biology and a review of the literature (including reviews by Fadlallah 1983, Richmond and Hunter 1990, and Richmond 1997). Although Hawaiian coral taxonomy is currently in a state of flux, Maragos (1995) was used as a guide (see Maragos 1977 for reported synonyms).

\section{RESULTS}

Information on modes and timing of gamete and planula release for 24 of roughly $50 \mathrm{Ha}$ waiian scleractinian coral species (Maragos 1995 ) is provided in Table 1 . The data cover the majority of the most common inshore 
TABLE 1

Reproductive Characteristics of Hawaiian Scleractinian Coral Species Listed by Maragos (1995)

\begin{tabular}{|c|c|c|c|c|c|c|c|}
\hline Species & $\operatorname{Sex}^{a}$ & Mode ${ }^{b}$ & Season $^{c}$ & Moon Phase & $\begin{array}{l}\text { Spawning } \\
\text { Times }\end{array}$ & $\begin{array}{l}\text { Location of } \\
\text { Fertilization }\end{array}$ & Reference \\
\hline \multicolumn{8}{|l|}{ ACROPORIDAE } \\
\hline Acropora cytberea (Dana, 1846) & $\mathrm{H}$ & *S & ${ }^{*} \mathrm{Lt} . \mathrm{Sp}-\mathrm{Sr}$ & & *June-Aug. & & Kenyon $(1992,1994)$ \\
\hline $\begin{array}{l}\text { A. bumilis (Dana, } 1846 \text { ) } \\
\text { A. paniculata Verrill, } 1902\end{array}$ & $\mathrm{H}$ & ${ }^{*} \mathrm{~S}$ & Lt. $S_{p}$ & ${ }^{*} 1$ st qtr & *June & *Surface & Kenyon $(1992,1994)$ \\
\hline A. valida (Dana, 1846) & $\mathrm{H}$ & ${ }^{*} \mathrm{~S}$ & $\mathrm{Sr}$ & *New-4th qtr? & *July-Aug. & *Surface & Kenyon $(1992,1994)$ \\
\hline Montipora capitata (Dana, 1846) & $\mathrm{H}$ & $\mathrm{S}$ & Lt. Sp-Sr & New-1st qtr & $\begin{array}{l}\text { May-Sept., } \\
20: 45-22: 30\end{array}$ & Surface & $\begin{array}{l}\text { Heyward (1986), } \\
\text { Hodgson }(1988), \\
\text { Hunter }(1988 b), \\
\text { Cox }(1991)\end{array}$ \\
\hline M. dilatata Studer, 1901 & $\mathrm{H}$ & $\mathrm{S}$ & $\mathrm{Sr}$ & $\begin{array}{l}\text { New, } \\
\text { Full-3rd qtr }\end{array}$ & $\begin{array}{l}\text { July-Aug., } \\
20: 30-21: 45\end{array}$ & Surface & $\begin{array}{l}\text { Heyward (1986), } \\
\text { Hodgson }(1988), \\
\text { Hunter }(1988 b)\end{array}$ \\
\hline M. flabellata Studer, 1901 & $\mathbf{H}$ & $S$ & $\mathrm{Sr}-{ }^{\star} \mathrm{F}$ & & $\begin{array}{l}\text { July- }{ }^{*} \text { Sept., } \\
\text { 21:05-21:50 }\end{array}$ & Surface & $\begin{array}{l}\text { Heyward (1986), this } \\
\text { study }\end{array}$ \\
\hline M. patula Verrill, 1864 & $\mathrm{H}$ & $S$ & $\mathrm{Sr}$ & $\begin{array}{l}\text { New-1st qtr, } \\
\text { Full-3rd qtr }\end{array}$ & $\begin{array}{l}\text { July-Sept., } \\
\text { 22:05-23:10 }\end{array}$ & Surface & $\begin{array}{l}\text { Hodgson (1988), this } \\
\text { study }\end{array}$ \\
\hline M. studeri Vaughan, 1907 & $\mathrm{H}$ & $\mathrm{S}$ & $\mathrm{Sr}$ & $\begin{array}{l}\text { New-1st qtr, } \\
\text { Full-3rd qtr }\end{array}$ & $\begin{array}{l}\text { July-Sept., } \\
22: 23-23: 00\end{array}$ & Surface & $\begin{array}{l}\text { Heyward (1986), } \\
\text { Mate (1998) }\end{array}$ \\
\hline $\begin{array}{l}\text { M. tuberculosa (Lamarck, 1816) } \\
\text { M. verrilli Vaughan, } 1907\end{array}$ & $\mathrm{H}$ & ${ }^{*} \mathrm{~S}$ & $\mathrm{Sr}$ & Full-3rd qtr & July & ${ }^{\star}$ Surface & Heyward (1986) \\
\hline $\begin{array}{l}\text { AGARICIIDAE } \\
\text { Gardineroseris planulata (Dana, } 18 \\
\text { Leptoseris bawaitensis Vaughan, } 19 \\
\text { L. incrustans (Quelch, 1886) } \\
\text { L. mycetoseroides Wells, 1954 } \\
\text { L. papyracea (Dana, 1846) } \\
\text { L. scabra Vaughan, 1907 } \\
\text { L. tubulifera Vaughan, } 1907\end{array}$ & & & & & & & \\
\hline Pavona duerdeni Vaughan, 1907 & $\mathrm{G}$ & $\mathrm{S}$ & & & & *Water column & G. Hodgson, unpubl. \\
\hline P. maldivensis (Gardiner, 1905) & G & $\mathrm{S}$ & Lt. Sp & Full-3rd qtr & $\begin{array}{l}\text { June, } \\
\text { 19:05-20:15 }\end{array}$ & $\begin{array}{l}\text { "Water column/ } \\
\text { surface }\end{array}$ & $\begin{array}{l}\text { G. Hodgson, unpubl. } \\
\text { data; Mate (1998); } \\
\text { this study }\end{array}$ \\
\hline
\end{tabular}




\section{BALANOPHYLLIDAE}

Balanopbyllia sp. cf. affinis (Semper,

$$
\text { 1872) }
$$

B. hazvaiiensis Vaughan, 1907

\section{DENDROPHYLLIDAE \\ Tubastrea cocinea Lesson, 1831}

\section{FAVIIDAE}

Cypbastrea ocellina (Dana, 1846)

Leptastrea bottae (Milne-Edwards \&

Haime, 1850)

L. purpurea Dana, 1846

\section{FUNGIIDAE}

Cycloseris tenuis (Dana, 1846)

C. vaughani (Boschma, 1923)

Diaseris distorta (Michelin, 1843)

Fungia scutaria Lamarck, 1801

\section{POCILLOPORIDAE}

Pocillopora damicomis (Linnaeus, 1758)

$\mathrm{H}$

B

$\mathrm{Yr}$

P. eydouxi Milne-Edwards \& Haime, 1860

P. ligulata Dana, 1846

P. meandrina Dana, 1846
June-Jan.,
diurnal and

nocturnal

All

Polyps

*Water column

*Water column

Polyps
Full-3rd qtr

All

Apr.-May,
$07: 20-08: 15$

Diurnal and nocturnal
Edmondson (1929

1946), Jokiel et al

(1985); A. M.

Tarrant and S.P.K. unpubl. data

Edmondson (1929, 1946), Stimson (1978), Jokiel et al. (1985), Wright

(1986)

G. Hodgson, unpubl. data

. Hodgson, unpubl. data

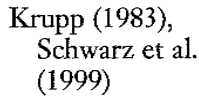

Krupp (1983),

Schwarz et al. (1999)

Polyps

Edmondson (1946), Reed (1971),

Harrigan (1972),

Stimson (1978)

Richmond and

Jokiel (1984),

Jokiel (1985)

Stimson (1978) Fiene-Severns (1998); S.P.K., A. M. Tarrant, and E.F.C., unpubl. data 
TABLE 1 (continued)

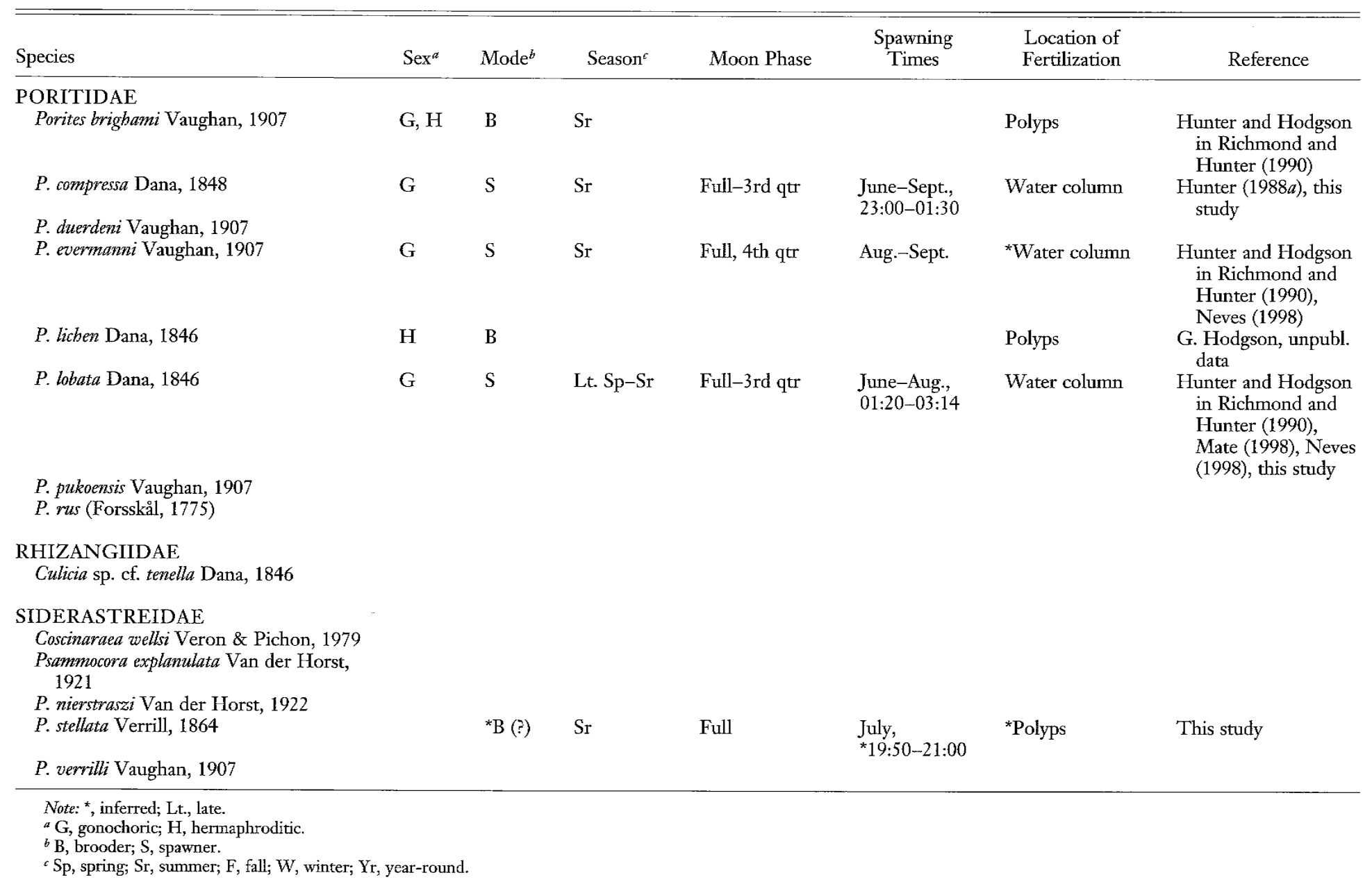




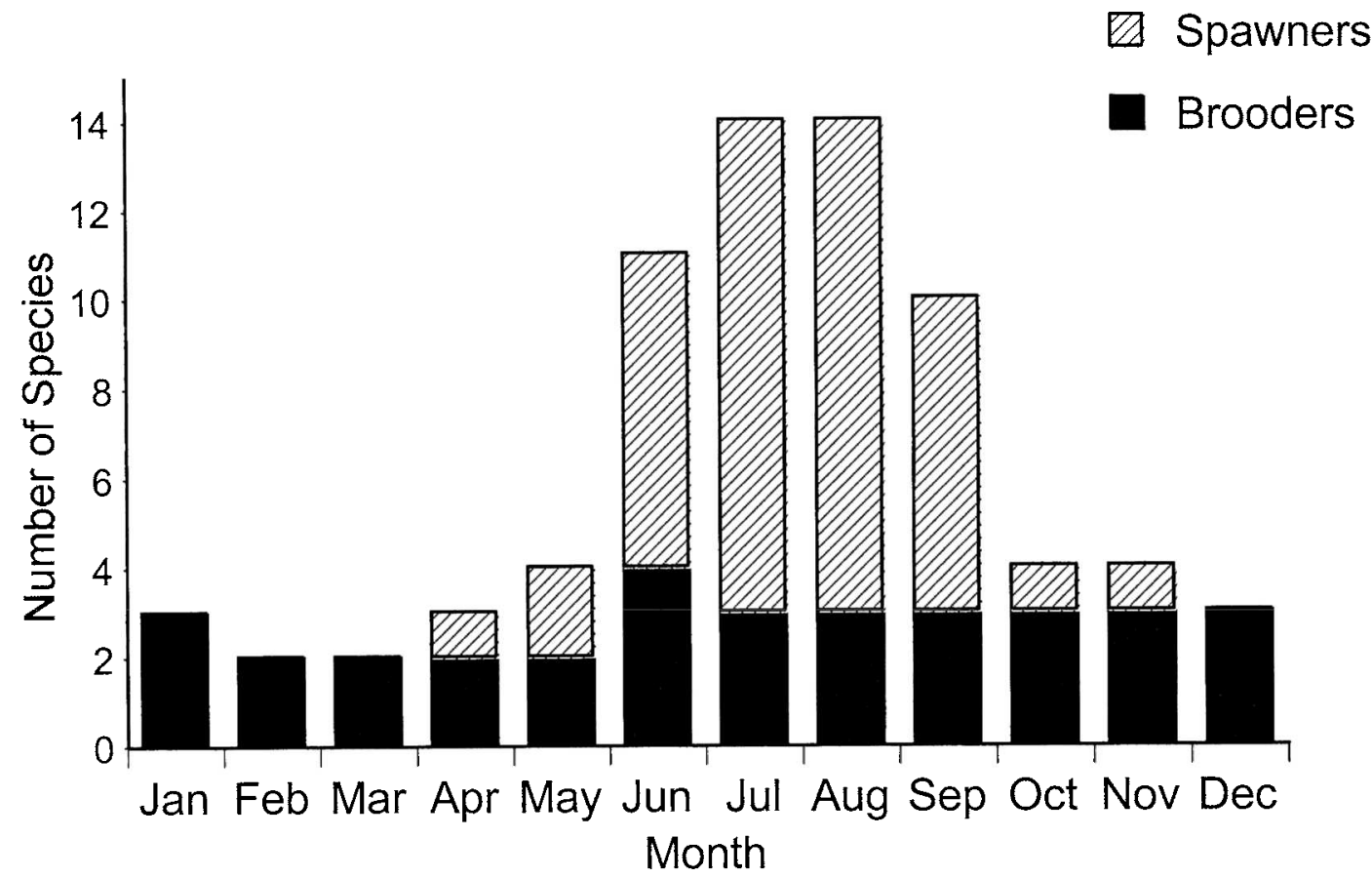

FIGURE 1. Known number of scleractinian coral species planulating and spawning each month in Hawaiian waters.

shallow-water species but are far from complete. Six $(25 \%)$ of the 24 species brood larvae, $10(42 \%)$ are broadcast-spawning hermaphrodites, and eight (33\%) are gonochoric broadcast spawners. Seventeen species $(71 \%)$ display peak reproductive development and gamete or planula release during summer, at least five species $(21 \%)$ extend release into fall, three species $(13 \%)$ continue release into winter, and nine species (38\%) begin or continue reproductive release in the spring (Figure 1). Fertilization in the Hawaiian Acroporidae is overwhelmingly a surface phenomenon. In brooding species syngamy is presumed to take place within polyps. Zygote formation in gonochoric broadcast spawners is likely to occur within the water column, but surface fertilization may also take place. Although specific timing of gamete release appears discrete and predictable, spawning for most species occurs over a number of days and months, indicating variability and possible plasticity in seasonal synchrony of spawning events.
The classification of Psammacora stellata as a brooder in this study is tentative and in need of verification. It is based on the tank collection of swimming coral larvae $45 \mathrm{~min}$ after previous examination of secluded colonies. We made direct observations on mode and timing of reproductive release of Montipora patula colonies over multiple reproductive seasons, as well as observations confirming the reproductive activities of $M$. capitata, Pavona varians, Tubastrea coccinea, Cypbastrea ocellina, Fungia scutaria, Pocillopora damicornis, P. meandrina, Porites compressa, and P. Lobata. Observations of Montipora flabellata spawning were limited, and species identification of the morphological variant used in this study is in need of verification and congruence of multiple coral taxonomists.

\section{DISCUSSION}

Any assessment of potential impacts to Hawaiian reef corals must take into consideration local population structure and timing 
and location of all stages of coral reproductive cycles, including recruitment and growth. Reproductive stages for each species are susceptible to different impacts at particular times of the year, corresponding to spatial and temporal variation of reproductive activities. Because of the open nature of the marine system, the ultimate effect of any localized impact is also likely to be incurred by one or more sink reef areas within the region of the metapopulation, even those remote from the reproductive source area (Keough and Black 1996, Raimondi and Reed 1996).

Negative impacts to one or multiple stages of the reproductive process are likely to have a cascading effect on the success of the remaining stages. For instance, Hughes et al. (2000) discovered a strong link between adult fecundity and recruitment in species of Australian Acropora and suggested that even a small decline in fecundity will result in a major reduction in overall recruitment. Small changes in fertilization rates or the rate of mortality of embryos and larvae also may have dramatic effects on the recruitment of dispersing offspring (Underwood and Fairweather 1989, Levitan 1995, Lasker et al. 1996). The onset and rate of coral gamete development appear to be influenced by environmental cues and conditions (SzmantFroelich et al. 1980, Harrison and Wallace 1990, Szmant and Gassman 1990, Fan and Dai 1999). Physical and/or chemical impacts to the benthic community over the course of gamete maturation thus have the potential to disrupt the development process, resulting in loss of synchronization and/or a reduction in overall fecundity. Sedimentation, reduced salinity from runoff, oil residues and dispersants, heavy metals, and various chemical waste products may interfere with fertilization, embryonic development, and coral planula survival (Acevedo 1991, Goh 1991, Harrison 1993, Richmond 1993, Peters et al. 1997, Palaki 1998, Gilmour 1999, ReicheltBrushett and Harrison 1999, Negri and Heyward 2000, 2001). Larvae of many marine invertebrates including corals actively select the substrate upon which they settle (Crisp 1974, Keough and Downes 1982, Morse 1990, Pawlik 1992, Morse et al. 1996,
Raimondi and Morse 2000). Appropriate cues for coral settlement include physical stimuli and, in many cases, specific biochemical inducer molecules (Morse et al. 1996, Heyward and Negri 1999, Raimondi and Morse 2000). Factors such as high sediment levels have been shown to inhibit coral larval settlement and persistence (Hodgson 1990, Babcock and Davies 1991, Hunte and Wittenberg 1992, Te 1992, Gilmour 1999). Herbicides, pesticides, heavy metals, oils and dispersants, human drug by-products, and other derived chemical compounds may act as waterborne toxicants that have inhibitory effects on coral recruitment as a result of reactions with larvae, settlement inducer molecules, and/or inducer-producing communities (Richmond 1993, 1997, Peters et al. 1997, Negri and Heyward 2000, 2001, Reichelt-Brushett and Harrison 2000).

Little is known about developmental stimuli or periods of gametogenesis for corals in Hawai'i. Studies of corals in other regions demonstrate that gametogenesis may begin from 2.5 to over 15 months before gamete or planula release (Wallace 1985, Babcock et al. 1986, Szmant 1986, Harrison and Wallace 1990). In Hawai'i, the discharge of coral reproductive products tends to take place over the course of 1 to 2 hours at a predictable time and appears in some cases to correspond to a particular lunar cycle (Table 1). Release recurs in many species over a number of consecutive days, with populations spawning over two to four consecutive months or planulating throughout the year (Table 1). Gamete viability limits the period of fertilization to within hours of spawning (Heyward and Babcock 1986, Hodgson 1988, Hunter 1988a, Oliver and Babcock 1992, Kenyon 1994, Mate et al. 1998). Embryonic development may proceed on the order of days (Babcock and Heyward 1986, Hunter 1988a, Harrison and Wallace 1990, Richmond 1997, Mate et al. 1998; S.P.K., unpubl. data). Coral larvae recruit year-round, but the vast majority of settlement takes place during summer and fall subsequent to spawning of the most abundant species (Fitzhardinge 1993; S.P.K., unpubl. data; E. K. Brown, unpubl. data). Long periods of growth on the order of months to 
years may be required before metamorphosed polyps recruit to the visible (sensu Wallace 1983) coral population (S.P.K., unpubl. data; E. K. Brown, unpubl. data).

Hawaiian species for which observations on reproductive mode and timing remain to be made tend to be less abundant, have low population densities, and/or are less accessible in their Hawaiian distributions. Few reports on the reproductive habits of these species in other locations were found (Gardineroseris planulata [Glynn et al. 1996], Pocillopora eydouxi [Kinzie 1993], Porites rus [Richmond and Hunter 1990]). Intraspecific variation in spawning times, sex, and/or modes across geographic distributions for many scleractinian species (see Harrison and Wallace 1990, Richmond and Hunter 1990, Ward 1992, Richmond 1997, Glynn et al. 2000) suggests that inferences on the reproductive timing and characteristics of species yet to be investigated in Hawaiian waters need be made with caution or not at all.

Hawaiian corals do not appear to be unique with regard to reproductive mode and timing. Discrete species gamete release over the course of several days and months has been noted in various geographic regions (Richmond and Hunter 1990, Hayashibara et al. 1993, Richmond 1997) and may increase reproductive success by allowing species to take advantage of environmental variability over time (Harrison and Wallace 1990, Richmond and Hunter 1990). Extended planulae release and spawning across spring and summer months is common to corals in other areas (Richmond and Hunter 1990, Richmond 1997). Mass overlap of species spawning as has been found in areas such as the Great Barrier Reef and Japan (Harrison and Wallace 1990, Richmond and Hunter 1990, Hayashibara et al. 1993) is not apparent in Hawaiian waters. Causal factors of mass spawning events have yet to be resolved. The probability of mass species spawning in Hawai' $i$ is presumably lower because of the relatively depauperate scleractinian species richness of the region.

Sound natural resource management and conservation must be based on a detailed understanding of reef processes if we are to successfully develop coastal areas in a manner that minimizes impacts to coral reef ecosystems. Our current ability to assess human impacts on coral reproductive dynamics is limited by a number of factors, including natural variation in reproduction, complex and/or synergistic physiological responses of corals to stresses, the lack of a catalog of known impacts and their sources, and incomplete knowledge of coral regional metapopulation boundaries. A few general precautionary guidelines, however, can be made. In particular, special attention should be given to minimizing benthic impacts, including chronic reductions in light, year-round, encompassing all periods of gamete development, recruitment, and growth of all Hawaiian coral species. Dredging or other damaging activities, including mitigation efforts such as the transplantation of corals, should be scheduled to follow the reproductive season of species that will be physically impacted. Changes in water column parameters, such as from fine-grained sedimentation, oil, petrol, and toxic chemical releases, are likely to have the greatest impact when they occur during April through November, the period of synchronous gamete release, fertilization, embryonic development, and dispersal of the dominant Hawaiian corals (Figure 1). Investigations of the effects of steroids, hormones, and other chemical pollutants are needed, as is information on gametogenesis and recruitment processes for all, and reproductive timing, mode, and plasticity for many Hawaiian coral species.

Successful corals tend to be long-lived and experience multiple reproductive events, thus short-term, infrequent, limited, or controlled disturbances might have a negligible longterm impact on reproduction and population dynamics. Further studies of the reproductive biology of Hawaiian corals will elucidate the magnitude of these types of impacts on the long-term dynamics of coral populations. It is important to recognize, however, that the focus of attention should not be restricted to corals, but expanded to cover the range of contributors to reef ecosystem functions, including other invertebrates, vertebrates, plants, algae, and protists. 


\section{ACKNOWLEDGMENTS}

We thank Paul Jokiel for his support and Cindy Hunter and an anonymous reviewer for comments that improved the manuscript.

\section{Literature Cited}

Acevedo, R. 1991. Preliminary observations on effects of pesticides carbaryl, naphthol, and chlorpyrifos on planulae of the hermatypic coral Pocillopora damicomis. Pac. Sci. 45:287-289.

Babcock, R., and P. Davies. 1991. Effects of sedimentation on settlement of Acropora millepora. Coral Reefs 9:205-208.

Babcock, R. C., and A. J. Heyward. 1986. Larval development of certain gametespawning scleractinian corals. Coral Reefs 5:111-116.

Babcock, R. C., G. D. Bull, P. L. Harrison, A. J. Heyward, J. K. Oliver, C. C. Wallace, and B. L. Willis. 1986. Synchronous spawnings of 105 scleractinian coral species on the Great Barrier Reef. Mar. Biol. (Berl.) 90:379-394.

Brown, B. E., and L. S. Howard. 1985. Assessing the effects of "stress" on reef corals. Adv. Mar. Biol. 22:1-63.

Coma, R., M. Ribes, J. Gili, and M. Zabala. 1998. An energetic approach to the study of life-history traits of two modular colonial benthic invertebrates. Mar. Ecol. Prog. Ser. 162:89-103.

Cox, E. F. 1991. Interactions between trophic levels on coral reefs: Scleractinian corals and corallivorous butterflyfishes in Hawaii. Ph.D. diss., University of New Mexico, Albuquerque.

Crisp, D. J. 1974. Factors influencing the settlement of marine invertebrate larvae. Pages 177-265 in P. T. Grant and A. M. Mackie, eds. Chemoreception in marine organisms. Academic Press, New York.

Edmondson, C. H. 1929. Growth of Hawaiian corals. Bernice P. Bishop Mus. Bull. 58:1-38.

—_. 1946. Behavior of coral planulae under altered saline and thermal conditions. Occas. Pap. Bernice Pauahi Bishop Mus. 18:283-304.
Fadlallah, Y. H. 1983. Sexual reproduction, development and larval biology in scleractinian corals. Coral Reefs 2:129-150.

Fan, T., and C. Dai. 1999. Reproductive plasticity in the reef coral Echinopora lamellosa. Mar. Ecol. Prog. Ser. 190:297301.

Fiene-Severns, P. 1998. A note on synchronous spawning in the reef coral Pocillopora meandrina at Molokini Islet, Hawaii. Pages 23-26 in E. F. Cox, D. A. Krupp, and P. L. Jokiel, eds. Reproduction in reef corals, results of the 1997 Edwin W. Pauley summer program in marine biology. Hawai'i Inst. Mar. Biol. Tech. Rep. 42.

Fitzhardinge, R. 1993. The ecology of juvenile Hawaiian corals. Ph.D. diss., University of Hawai' $i$ at Mānoa, Honolulu.

Gilmour, J. 1999. Experimental investigation into the effects of suspended sediment on fertilization, larval survival and settlement in a scleractinian coral. Mar. Biol. (Berl.) 135:451-462.

Glynn, P. W., S. B. Colley, N. J. Gassman, K. Black, J. Cortes, and J. L. Mate. 1996. Reef coral reproduction in the eastern Pacific: Costa Rica, Panama, and the Galapagos Islands (Ecuador). III. Agariciidae (Pavona gigantea and Gardineroseris planulata). Mar. Biol. (Berl.) 125:579-601.

Glynn, P. W., S. B. Colley, J. H. Ting, J. L. Mate, and H. M. Guzman. 2000. Reef coral reproduction in the eastern Pacific: Costa Rica, Panama and Galapagos Islands (Ecuador). IV. Agariciidae, recruitment and recovery of Pavona varians and Pavona sp. a. Mar. Biol. (Berl.) 136:785-805.

Goh, B. P. L. 1991. Mortality and settlement success of Pocillopora damicornis planula larvae during recovery from low levels of nickel. Pac. Sci. 45:276-286.

Harrigan, J. F. 1972. The planula larva of Pocillopora damicornis: Lunar periodicity of spawning and substratum selection behavior. Ph.D. diss., University of Hawai' $i$ at Mānoa, Honolulu.

Harrison, P. L. 1993. Coral spawning on the Great Barrier Reef. Search (Syd.) 24:4548.

Harrison, P. L., and C. C. Wallace. 1990. Reproduction, dispersal and recruitment of 
scleractinian corals. Pages 133-207 in Z. Dubinsky, ed. Ecosystems of the world, coral reefs. Elsevier Science Publishers B.V., Amsterdam.

Hayashibara, T., K. Shimoike, T. Kimura, S. Hosaka, A. Heyward, P. Harrison, K. Kudo, and M. Omori. 1993. Patterns of coral spawning at Akajima Island, Okinawa, Japan. Mar. Ecol. Prog. Ser. 101: 253-262.

Heyward, A. J. 1986. Sexual reproduction in five species of the coral Montipora. Pages 170-178 in P. L. Jokiel, R. H. Richmond, and R. A. Rogers, eds. Coral reef population biology. Hawai i Inst. Mar. Biol. Tech. Rep. 37, SeaGrant Coop. Rep. UNIHI-SEAGRANT-CR-80-01.

Heyward, A. J., and R. C. Babcock. 1986. Self-and cross-fertilization in scleractinian corals. Mar. Biol. (Berl.) 90:191-195.

Heyward, A. J., and A. P. Negri. 1999. Natural inducers for coral larval metamorphosis. Coral Reefs 18:273-279.

Hodgson, G. 1988. Potential gamete wastage in synchronously spawning corals due to hybrid inviability. Proc. 6th Int. Coral Reef Symp., Australia 2:707-714.

- - 1990. Sediment and the settlement of larvae of the reef coral Pocillopora damicornis. Coral Reefs 9:41-43.

Hughes, T. P., A. H. Baird, E. A. Dinsdale, N. A. Moltschaniwskyj, M. S. Pratchett, J. E. Tanner, and B. L. Willis. 2000. Supplyside ecology works both ways: The link between benthic adults, fecundity, and larval recruits. Ecology 81:2241-2249.

Hunte, W., and M. Wittenberg. 1992. Effects of eutrophication and sedimentation on juvenile corals. II. Settlement. Mar. Biol. (Berl.) 114:625-631.

Hunter, C. L. 1988a. Genotypic diversity and population structure of the Hawaiian reef coral Porites compressa. Ph.D. diss., University of Hawai' $i$ at Mānoa, Honolulu.

- 1988b. Environmental cues controlling spawning in two Hawaiian corals, Montipora verrucosa and $M$. dilitata. Proc. 6th Int. Coral Reef Symp., Australia 2: 727-732.

Jokiel, P. L. 1985. Lunar periodicity of planula release in the reef coral Pocillopora damicornis in relation to various environmental factors. Proc. 5th Int. Coral Reef Congr., Tahiti 4:307-312.

Jokiel, P. L, R. Y. Ito, and P. M . Liu. 1985. Night irradiance and synchronization of lunar release of planula larvae in the reef coral Pocillopora damicomis. Mar. Biol. (Berl.) 88:167-174.

Kenyon, J. C. 1992. Sexual reproduction in Hawaiian Acropora. Coral Reefs 11:37-43. - 1994. Hybridization and polyploidy in the coral genus Acropora. Ph.D. diss., University of Hawai'i at Mānoa, Honolulu.

Keough, M. J., and K. P. Black. 1996. Predicting the scale of marine impacts: Understanding planktonic links between populations. Pages 199-232 in R. J. Schmitt and C. W. Osenberg, eds. Detecting ecological impacts, concepts and applications in coastal habitats. Academic Press, San Diego.

Keough, M. J., and B. J. Downes. 1982. Recruitment of marine invertebrates: The role of active larval choices and early mortality. Oecologia (Berl.) 54:348-352.

Kinzie, R. A. 1993. Spawning in the reef corals Pocillopora verrucosa and $P$. eydouxi at Sesoko Island, Okinawa. Galaxea 11:93105.

Krupp, D. A. 1983. Sexual reproduction and early development of the solitary coral Fungia scutaria (Anthozoa: Scleractinia). Coral Reefs 2:159-164.

Lasker, H. R., D. A. Brazeau, J. Calderon, $M$. A. Coffroth, R. Coma, and K. Kim. 1996. In situ rates of fertilization among broadcast spawning gorgonian corals. Biol. Bull. (Woods Hole) 190:45-55.

Levitan, D. R. 1995. The ecology of fertilization in free-spawning invertebrates. Pages 123-156 in L. McEdwards, ed. Ecology of marine invertebrate larvae. CRC Press, Boca Raton, Florida.

Maragos, J. E. 1977. Order Scleractinia, stony corals. Pages 158-241 in D. M. Devaney and L. G. Eldredge, eds. Reef and shore fauna of Hawaii. 1. Protozoa through Ctenophora. Bernice P. Bishop Mus. Spec. Publ. 64 (1). 
shallow-water stony coral species from Hawaii (Cnidaria: Anthozoa: Scleractinia). Bishop Mus. Occas. Pap. 42:54-55.

Mate, J. L. 1998. New reports on the timing and mode of reproduction of Hawaiian corals. Page 7 in E. F. Cox, D. A. Krupp, and P. L. Jokiel, eds. Reproduction in reef corals, results of the 1997 Edwin W. Pauley summer program in marine biology. Hawai'i Inst. Mar. Biol. Tech. Rep. 42 (abstract).

Mate, J. L., J. Wilson, S. Field, and E. G. Neves. 1998. Fertilization dynamics and larval development of the scleractinian coral Montipora verrucosa in Hawai'i. Pages 27-40 in E. F. Cox, D. A. Krupp, and P. L. Jokiel, eds. Reproduction in reef corals, results of the 1997 Edwin W. Pauley summer program in marine biology. $\mathrm{Ha}$ wai'i Inst. Mar. Biol. Tech. Rep. 42.

Morgan, S. G. 1995. The timing of larval release. Pages 157-191 in L. McEdwards, ed. Ecology of marine invertebrate larvae. CRC Press, Boca Raton, Florida.

Morse, A. N. C., K. Iwao, M. Baba, K. Shimoike, T. Hayashibara, and $M$. Omori. 1996. An ancient chemosensory mechanism brings new life to coral reefs. Biol. Bull. (Woods Hole) 191:149-154.

Morse, D. E. 1990. Recent progress in larval settlement and metamorphosis: Closing the gaps between molecular biology and ecology. Bull. Mar. Sci. 46:465-483.

Negri, A. P., and A. J. Heyward. 2000. Inhibition of fertilization and larval metamorphosis of the coral Acropora millepora (Ehrenberg, 1834) by petroleum products. Mar. Pollut. Bull. 41:420-427.

- 2001. Inhibition of coral fertilization and larval metamorphosis by tributyltin and copper. Mar. Environ. Res. 51:17-27.

Neves, E. G. 1998. Histological analysis of reproductive trends of three Porites species from Kaneohe Bay, Hawaii. Pages 9-22 in E. F. Cox, D. A. Krupp, and P. L. Jokiel, eds. Reproduction in reef corals, results of the 1997 Edwin W. Pauley summer program in marine biology. Hawai'i Inst. Mar. Biol. Tech. Rep. 42.

Oliver, J., and R. Babcock. 1992. Aspects of the fertilization ecology of broadcast spawning corals: Sperm dilution effects and in situ measurements of fertilization. Biol. Bull. (Woods Hole) 183:409-417.

Palaki, A. 1998. The effect of salinity on fertilization success and survival and settlement of larvae of Fungia scutaria and Pocillopora damicomis. Pages 73-82 in E. F. Cox, D. A. Krupp, and P. L. Jokiel, eds. Reproduction in reef corals, results of the 1997 Edwin W. Pauley summer program in marine biology. Hawai'i Inst. Mar. Biol. Tech. Rep. 42.

Pawlik, J. R. 1992. Chemical ecology of the settlement of benthic marine invertebrates. Oceanogr. Mar. Biol. Annu. Rev. 30:273335.

Peters, E. C., N. J. Gassman, J. C. Firman, R. H. Richmond, and E. A. Power. 1997. Ecotoxicity of tropical marine ecosystems. J. Environ. Toxic Chem. 16:12-40.

Raimondi, P. T., and A. N. Morse. 2000. The consequences of complex larval behavior in a coral. Ecology 81:3193-3211.

Raimondi, P. 'T., and D. C. Reed. 1996. Determining the spatial extent of ecological impacts caused by local anthropogenic disturbances in coastal marine habitats. Pages 179-198 in R. J. Schmitt and C. W. Osenberg, eds. Detecting ecological impacts, concepts and applications in coastal habitats. Academic Press, San Diego.

Reed, S. A. 1971. Techniques for raising the planula larvae and newly settled polyps of Pacillopora damicornis. Pages 66-72 in H. M. Lenhoff, L. Muscatine, and L. V. Davis, eds. Experimental coelenterate biology. University of Hawai'i Press, Honolulu.

Reichelt-Brushett, A. J., and P. L. Harrison. 1999. The effect of copper, zinc and cadmium on fertilization success of gametes from scleractinian reef corals. Mar. Pollut. Bull. 38:182-187.

2000. The effect of copper on the settlement success of larvae from the scleractinian coral Acropora tenuis. Mar. Pollut. Bull. 41:385-391.

Richmond, R. H. 1993. Coral reefs: Present problems and future concerns resulting from anthropogenic disturbance. Am. Zool. 33:524-536. 
1997. Reproduction and recruitment in corals: Critical links in the persistence of reefs. Pages 175-196 in C. Birkeland, ed. Life and death of coral reefs. Chapman \& Hall, New York.

Richmond, R. H., and C. L. Hunter. 1990. Reproduction and recruitment of corals: Comparisons among the Caribbean, the tropical Pacific, and the Red Sea. Mar. Ecol. Prog. Ser. 60:185-203.

Richmond, R. H., and P. L. Jokiel. 1984. Lunar periodicity in larva release in the reef coral Pocillopora damicornis at Enewetak and Hawaii. Bull. Mar. Sci. 34:280287.

Schwartz, J., D. A. Krupp, and V. M. Weis. 1999. Late larval development and onset of symbiosis in the scleractinian coral Fungia scutaria. Biol. Bull. (Woods Hole) 196:7079.

Stimson, J. S. 1978. Mode and timing of reproduction in some common hermatypic corals of Hawaii and Enewetak. Mar. Biol. (Berl.) 48:173-184.

Szmant, A. M. 1986. Reproductive ecology of Caribbean reef corals. Coral Reefs 5:4354.

Szmant, A. M., and N. J. Gassman. 1990. The effects of prolonged "bleaching" on the tissue biomass and reproduction of the reef coral Montastrea annularis. Coral Reefs $8: 217-224$.

Szmant-Froelich, A. M., P. Yevich, and
M. E. Q. Pilson. 1980. Gametogenesis and early development of the temperate coral Astrangia danae (Anthozoa: Scleractinia). Biol. Bull. (Woods Hole) 158:257-269.

Te, F. T. 1992. Response to higher sediment loads by Pocillopora damicomis planulae. Coral Reefs 11:131-134.

Underwood, A. J., and P. G. Fairweather. 1989. Supply-side ecology and benthic marine assemblages. Trends Ecol. Evol. Biol. 4:16-20.

Wallace, C. C. 1983. Visible and invisible recruitment. Pages 259-261 in J. T. Baker, R. M. Carter, P. W. Sammarco, and K. P. Stark, eds. Proceedings, Inaugural Great Barrier Reef Conference, Townsville, 1983. JCU Press, Townsville, Australia. 1985. Reproduction, recruitment and fragmentation in nine sympatric species of the coral genus Acropora. Mar. Biol. (Berl.) $88: 217-233$.

Ward, S. 1992. Evidence for broadcast spawning as well as brooding in the scleractinian coral Pocillopora damicornis. Mar. Biol. (Berl.) 112:641-646.

Wright, N. 1986. Aspects of reproduction and planula development in the reef coral Cyphastrea ocellina. Pages 179-192 in P. L. Jokiel, R. H. Richmond, and R. A. Rogers, eds. Coral reef population biology. Hawai'i Inst. Mar. Biol. Tech. Rep. 37, SeaGrant Coop. Rep. UNIHI-SEAGRANT-CR80-01. 